\title{
Walter Neef Vickery, 1921-1995
}

Walter Neef Vickery was born on 14 September 1921 in London. An excellent humanistic education gave him a good command of Latin and ancient Greek, near-native fluency in French, as well as some knowledge of other European languages, notably German and Italian. In 1940, at the age of nineteen, he enlisted in the Royal Navy, serving five years as a gunner, partly on Norwegian vessels. On his discharge in 1945 he enrolled in Oxford University, where in 1948 he received the B.A. in Russian language and literature with first-class honors, followed by an M.A. in 1952. He remained at Oxford as a lecturer from 1948 until 1953, except for the year 1951-52, which he spent in Moscow, working under the auspices of the British Foreign Service for the U.S.British Joint Press Reading Service.

In 1953 Vickery emigrated to Canada. As a respite from intellectual pursuits, he worked two years as a laborer in a cement factory, apparently with great satisfaction. In 1955, however, he decided to resume his academic career and enrolled as a graduate student at Harvard. There he completed work for the Ph.D. in Slavic languages and literatures in three years. He subsequently taught at Indiana University as assistant and associate professor, 1958-64; at the University of Colorado as professor, 196569; and at Yale University as visiting professor, 1975. He joined the faculty of the University of North Carolina at Chapel Hill as professor in 1969 and remained in that position until his retirement in 1992. He has taken a permanent place in the history of the University of North Carolina as the founder of the Department of Slavic Languages, which he chaired from 1969 until 1974. He taught a wide repertory of courses on Russian literature, including Old Russian literature, the eighteenth century, versification, and seminars on individual authors. He also taught comparative versification for the Curriculum in Comparative Literature.

Perhaps as a result of his sojourn in Moscow in the early 1950s, Vickery's early scholarly work focused on the contemporary Soviet literary scene. His dissertation was eventually converted into a pioneering book, The Cult of Optimism (1963; reprint, 1976). He also coedited (with Hugh McLean) The Year of Protest, 1956 (1961; reprint, 1974), and translated Viktor Nekrasov's Kira Georgievna (1962).

In subsequent years, however, Vickery turned his attention almost exclusively to Russian poetry, mainly of the nineteenth century, approaching this subject with a warmly appreciative, but refreshingly unpretentious and unsentimental attitude. He became a recognized authority on questions of versification, publishing numerous articles on this topic; with Edward Stankiewicz, he also edited a translation of Viktor Zhirmunskii's Introduction to Metrics (1966). Vickery was one of the few western scholars to have an article published in a Soviet journal (Russkaia literatura). He was also interested in poets' biographies and in general literary topics. His study of Pushkin's duel and death (The Death of a Poet, 1968) was widely admired for its sober common sense as well as its scholarly thoroughness. It was followed by an excellent introductory summary of Pushkin's life and works in the Twayne Series (1970), to date the most widely used English-language introduction to Russia's national poet. A revised edition was published in 1993. The breadth of Vickery's interests is also indicated by the XVIIIth-Century Russian Reader he coedited with C. L. Drage (1969) and by the international symposium he convened at the University of North Carolina, whose proceedings he coedited with Bogdan Sagatov under the title Alexander Blok Centennial Conference (1984). After retiring in 1992 and despite illness, Vickery completed a comprehensive study of the life and work of Mikhail Lermontov, which is now being considered for publication. Walter Vickery will be remembered by his colleagues and generations of students for his broad culture, remarkable intelligence, and personal

Slavic Review 55, no. 3 (Fall 1996) 
charm. He was very much a scholar of Russian literature, but his interests were not confined to his own field. As a senior professor he took courses and became quite an expert in mathematical statistics as well as Greek literature. He also loved the moun tains and climbed all fifty-four of Colorado's 14,000-foot peaks. He spent the all too few years of his retirement in the beautiful setting of Seeley Lake, Montana, where he died on 15 October 1995. He is survived by his sister, Anne, by his six children, Ian, Peter, Tina, Helen, Carl, and Eileen, and by six grandchildren.

\author{
Paul Drbreczeny \\ LAWRENCE: Frinberg: \\ University of North Carolina, Chapel Hill \\ Hugh MCLEAN \\ University of California, Berkeley \\ February 1996
}

\title{
Iakov Solomonovich Lur'e, 1921-1996
}

Iakov Solomonovich Lur'e, the distinguished Russian medievalist and cultural historian, passed away on 18 March 1996 in St. Petersburg following abdominal surgery. He was well known to many American colleagues as an outstanding member of the generation of scholars who emerged in the postwar years and who, during the subsequent thaw, struggled to revive the academic standards and interests of the distinguished pre-Stalinist schools of Russian historiography.

The son of the famous classicist Solomon Iakovlevich Lur'e (1891-1964), Lur'e was a precocious student, entering Leningrad State University at sixteen and obtaining his kandidat degree at twenty-one with a dissertation on Anglo-Russian relations in the sixteenth century. In these early years his most important teacher was the historian Mikhail Dmitrievich Priselkov (1881-1941), whom he admired throughout his life. (The preparation of a collection of Priselkov's works was one of Lur'e's last undertakings.) After wartime evacuation in Eniseisk, Vologda, and Arkhangel'sk, where he began to teach, he returned to Leningrad and became a popular instructor in the Herzen Pedagogical Institute. In 1949, however, he was labeled a "rootless cosmopolitan," removed from his job, and denied formal employment for four years. Although he eventually found a home as a research fellow, first in the Museum of the History of Religion (Kazanskii Sobor, 1953-56) and later in the Pushkinskii dom of the Soviet Academy in Leningrad (1956-82), he was never again allowed to teach.

His research continued unabated, however, even after he was forced out of the Pushkinskii dom by police pressure for having defended a young colleague against repression by the KGB. In fact, his last years were in many ways his most productive. Freed from the small and middling idiocies of the Soviet institut, he completed not only what may well be seen in retrospect as his most valuable historical monograph (Dve istorii Rusi XV veka, 1994), but also some works of interpretation, long in gestation, on his favorite prerevolutionary and Soviet authors (Posle L'va Tolstogo, 1993; V kraiu nepugannykh idiotov: Kniga ob Il'fe $i$ Petrove, 1983), and a reminiscence of his father (Istoriia odnoi zhizni, 1987). Lur'e particularly relished the publication of the latter two titles, which appeared under the pseudonyms Avel' Adamovich Kurdiumov and Bogdana Ikovlevna Koprzhiva-Lur'e, respectively.

Among American students of Muscovy, however, Lur'e will probably be best remembered for his important studies of Muscovite chronicles and ecclesiastical politics 